\title{
CONSEQUENCES OF ALCOHOL ABUSE/DEPENDENCE IN BRAZIL: DISABILITY-ADJUSTED LIFE YEARS (DALY)
}

\author{
GALLASSI, Andrea Donatti ${ }^{1}$ \\ NAKANO, Eduardo Yoshi
}

\begin{abstract}
SUMMARY: This study estimated the burden of alcohol use in Disability-Adjusted Life Years (DALY) for Brazil. The measures of DALY combines the measures of Years of Life Lost (YLL) and Years Lived with Disability (YLD), based on methodology of the Global Burden of Disease (GBD) and were presented using the rate of 1:10,000. Alcohol use was defined by ICD-10 F10-F10.9. We used outpatient treatment, admissions and mortality data and the disability weights specific for alcohol according with GBD to calculate the DALY-relevant measures. The total value of DALY in Brazil due to the alcohol use was 32.05, similar to what we observed in YLD total value [31.60] and different of the measure of the YLL total value [0.45]. There is important difference in DALY's value between gender, being the biggest at the age group 40-44 [158.10 male and 34.03 female]. The biggest loss of DALY's total value is at the 44 age group with 158.01 years. The impact of the DALY due to alcohol use represents the need to refine existing actions in prevention and treatment, seeking the search for better strategies that promote more responsible alcohol use and decrease individual and social harms.
\end{abstract}

Keywords: Alcohol Use. Public Health. Years of Life Lost. Years Lived with Disability.

RESUMO: Este estudo estimou a carga do uso de álcool em Anos de Vida Ajustados por Incapacidade (DALY) para o Brasil. O DALY combina os Anos de Vida Perdidos por Morte (YLL) e Anos de Vida Perdidos por Incapacidade (YLD) com base na metodologia da Carga Global de Doenças (GBD) e apresentados com base na taxa de 1:10.000. O consumo de álcool foi definido pela CID10 F10-F10.9. Foram utilizados dados de tratamento ambulatorial, internações e mortalidade e o "peso" da doença, específico para o uso de álcool de acordo com GBD, para calcular as medidas DALY. O valor total do DALY no Brasil pelo uso de álcool foi de 32,05, semelhante ao que observamos nos YLD [31,60] e diferente dos YLL [0,45]. Há uma diferença importante no valor de DALY entre gêneros, sendo maior na faixa etária 40-44 [158,10 masculino e 34,03 feminino]. A maior perda de valor de DALY está no grupo de 44 anos, com 158,01 anos. O impacto do DALY devido ao uso de álcool representa a necessidade de aperfeiçoarmos as ações de prevenção e tratamento, visando a busca de melhores estratégias que promovam uma utilização mais responsável de álcool e diminua os danos individuais e sociais.

Palavras-Chave: Uso de álcool. Saúde Pública. Anos de Vida Perdidos por Morte. Anos de Vida Perdidos por Incapacidade.

\section{INTRODUCTION}

Alcohol use - and specifically alcohol abuse - can result in a wide range of health and social problems. Key alcohol-related health problems include various cancers; diabetes; infectious and neuropsychiatric diseases (including alcohol use disorders); cardiovascular disease, liver and pancreatic diseases. On this basis, alcohol use is one of the primary risk factors for the global burden of disease (REHM;MONTEIRO, 2005).

Additionally, alcohol use constitutes a sizeable public health and social challenge, specifically since alcohol related-problems entail major health, social and economic consequences, and require comprehensive interventions (GALLASSI et al., 2008). Furthermore, alcohol dependence, as a chronic

\footnotetext{
${ }^{1}$ Faculdade de Ceilândia. Universidade de Brasília

${ }^{2}$ Departamento de Estatística. Universidade de Brasília - UnB
} 
disease condition, typically requires long-term treatment and care at considerable expense to public or other health care systems.

In this sense, there is a growing need and trend to assess the contribution of psychoactive drug use - including alcohol use - as a risk factor for the burden of disease, both globally as well as in individual national jurisdictions (DOLL; BINDER, 2004 e LIM, et al., 2012). A key purpose of these studies is to identify the respective contributory role of psychoactive drug use to disease burden outcomes, so as to ideally - develop and target interventions to reduce these negative consequences.

In Brazil, about 55\% of the general adult population are current alcohol users. Among drinkers, the prevalence of alcohol abuse (e.g., excessive drinking) and dependence is high (CEBRID, 2005). In the past decade, there was substantive increase in the number of frequent alcohol drinkers (i.e. those who drink at least once a week), from $45 \%$ to $54 \%$. Women presented the highest increase rate (from $29 \%$ in 2006 to 39\% in 2012)(LARANJEIRA et al., 2013). Additionally, an estimated 25\% of adults reported at least one social, occupation, familiar, legal or physical nature related problem to alcohol (SCHMIDT et al., 2011).

The objective of this paper was to compute the burden of disease for alcohol abuse/dependence in Brazil in 2007, based on the DALY's methodology as the global standard.

\section{MATERIAL AND METHODS}

Daly is a tool to evaluate the social burden caused by premature deaths and years lived with disability caused by the exposition to risk factors (WHITEFORD, et al., 2015; MURRAY, 1994 e MURRAY; LOPEZ, 1997). It is measured by the combination of two methodologies - Years Life Lost caused by premature death (YLL) and Years Lived with Disability (YLD).

The number of year life lost due to premature death (YLL) is the difference between age of death and life expectancy. As described in Gadelha et al. (2002), the mathematical expression of YLL is given by

$\mathrm{YLL}=\frac{K C e^{r \alpha}}{(r+\beta)^{2}}\left\{e^{-(r+\beta)(L+\alpha)}[-(r+\beta)(L+\alpha)-1]-e^{-(r+\beta) \alpha}[-(r+\beta) \alpha-1]\right\}+\frac{1-K}{r}\left(1-e^{1-r L}\right)$

where $C, K$ and $\beta$ are the parameters of the age-weighting function; $r$ is the discount rate; $\alpha$ is the age of the death and; $L$ is the expectancy life in the age $\alpha$. We considered in equation (1) the following values: $C=0.1658, K=1, \beta=0.04$ and $r=0.03$, since they have been used in other similar studies in Brazil (CAMPOS et al., 2015; NEDEL et al., 1999) and in other countries (LOPEZ et al., 2006).

To measure the morbidity and the mortality in a same "coin", should be defined a measured that attributes a numerical value at the time lived with a certain injury no fatal. The value of the time lived with a health situation no-fatal it's considered the weight of the disability. Thus, the mathematical expression of YLD is given by (GADELHA et al., 2002)

$$
\mathrm{YLD}=D \times \mathrm{YLL}
$$

where YLL is the number of year life lost presented by (1) and $D$ is the disability weight. The disability weight caused by alcohol use was $D=0.155$ (LOPEZ et al., 2006).

Both YLL and YLD were calculated using an age-weighting function (LOPEZ et al., 2006). The value attributed to the year of healthy life lost by children or senior were smaller than the value of healthy 
life lost by youths and adults. Also it was incorporating the discount rate of 3\%, which attributes a smaller value of lost for each year was used in this study. For example, the first year of life gets lost integrally, but the future years are going suffering the effect of the discount rate, where each lost year of healthy life is counted as $97 \%$ of the previous year (LOPEZ et al., 2006).

The data was collected using the Health National Database, called DATASUS, which is the Ministry of Health department responsible for gathering data from health services. Data from January to December 2007, from the Outpatient Information System (SIA/SUS) and the Hospital Information System (SIH/SUS) was selected using the International Statistical Classification of Diseases and Related Health Problems restricted by the F10 code, which classifies Alcohol Related Disorders (MINISTÉRIO DA SAÚDE B, 2009). The variables taken into account were: 1) the total number of admissions; 2) the total number of outpatient appointments; 3 ) the total number of death in public hospitals.

\section{RESULTS AND DISCUSSION}

Firstly we present the results from the YLL, followed by the results of YLD and finally the DALY attributable to alcohol consumption by sex and age. All indicators are presented using the rate of 1:10,000.

Table 1 presents the results from YLL disaggregated by sex and age. Men present higher indictors of premature death than women. The overall difference among men and women was about 9 times, with a stark discrepancy in the age group of 50 to 54 years. Additionally, this age group of men presented the largest value of YLL, with 3.27. Among women, the largest value of YLL was in the age group of 40 to 44 years, with 0.42 . While the men group reached the highest value of YLL, the women group presented a higher value of YLL earlier in life. Despite the fact that women presented earlier in life the consequences of alcohol abuse, men accounted for most of the total burden related with premature death due to alcohol consumption.

Table 1: YLL attributable to alcohol consumption by sex and age.

\begin{tabular}{lcccc}
\hline Age (years) & Men & Women & Overall & Sex ratio \\
\hline$\leq 19$ & 0.00 & 0.00 & $\mathbf{0 . 0 0}$ & --- \\
$20-24$ & 0.06 & 0.00 & $\mathbf{0 . 0 3}$ & --- \\
$25-29$ & 0.51 & 0.13 & $\mathbf{0 . 3 2}$ & 3.9 \\
$30-34$ & 0.80 & 0.07 & $\mathbf{0 . 4 3}$ & 11.9 \\
$35-39$ & 2.56 & 0.00 & $\mathbf{1 . 2 6}$ & --- \\
$40-44$ & 1.80 & 0.42 & $\mathbf{1 . 1 0}$ & 4.5 \\
$45-49$ & 2.49 & 0.31 & $\mathbf{1 . 3 9}$ & 8.1 \\
$50-54$ & 3.27 & 0.25 & $\mathbf{1 . 7 3}$ & 13.3 \\
$55-59$ & 1.67 & 0.25 & $\mathbf{0 . 9 4}$ & 6.8 \\
$60-64$ & 0.43 & 0.13 & $\mathbf{0 . 2 7}$ & 3.4 \\
$65-69$ & 1.27 & 0.12 & $\mathbf{0 . 6 7}$ & 10.4 \\
$70-74$ & 0.52 & 0.00 & $\mathbf{0 . 2 4}$ & --- \\
$75-79$ & 0.28 & 0.00 & $\mathbf{0 . 1 3}$ & --- \\
$\geq 80$ & 0.12 & 0.00 & $\mathbf{0 . 0 5}$ & --- \\
\hline Overall & $\mathbf{0 . 8 1}$ & $\mathbf{0 . 0 9}$ & $\mathbf{0 . 4 5}$ & $\mathbf{9 . 0}$ \\
\hline
\end{tabular}

Source: Elaborated by the authors.

Table 2 presents the results from YLD disaggregated by sex and age. Men presented higher indicators than women. For both men and women the highest values were found in the same age group of 40 to 44 . The age group in which occurred the largest loss of years due to incapacity, in both sex, extends among the years 20 to 64 , varying from 14.72 to 94.44 . Regarding the total values, in male, female and in both combined, YLD values were about 52.37, 10.95 and 31.60 , respectively. 
Table 2: YLD attributable to alcohol consumption by sex and age.

\begin{tabular}{lcccc}
\hline Age (years) & Men & Women & Overall & Sex ratio \\
\hline$<1$ & 0.24 & 0.06 & $\mathbf{0 . 1 5}$ & 3.8 \\
$01-04$ & 0.03 & 0.02 & $\mathbf{0 . 0 2}$ & 1.9 \\
$05-09$ & 0.15 & 0.03 & $\mathbf{0 . 0 9}$ & 4.4 \\
$10-14$ & 0.64 & 0.47 & $\mathbf{0 . 5 6}$ & 1.3 \\
$15-19$ & 6.40 & 2.04 & $\mathbf{4 . 2 5}$ & 3.1 \\
$20-24$ & 23.93 & 5.27 & $\mathbf{1 4 . 7 2}$ & 4.5 \\
$25-29$ & 59.53 & 10.36 & $\mathbf{3 4 . 9 7}$ & 5.7 \\
$30-34$ & 108.44 & 20.13 & $\mathbf{6 3 . 8 4}$ & 5.4 \\
$35-39$ & 142.89 & 26.53 & $\mathbf{8 3 . 8 2}$ & 5.4 \\
$40-44$ & 156.29 & 33.62 & $\mathbf{9 4 . 4 4}$ & 4.6 \\
$45-49$ & 142.11 & 30.94 & $\mathbf{8 5 . 8 5}$ & 4.6 \\
$50-54$ & 101.50 & 24.32 & $\mathbf{6 2 . 3 6}$ & 4.1 \\
$55-59$ & 60.32 & 12.61 & $\mathbf{3 5 . 9 2}$ & 4.8 \\
$60-64$ & 31.12 & 6.96 & $\mathbf{1 8 . 7 2}$ & 4.5 \\
$65-69$ & 16.17 & 4.10 & $\mathbf{9 . 8 9}$ & 3.9 \\
$70-74$ & 6.95 & 1.67 & $\mathbf{4 . 1 6}$ & 4.1 \\
$75-79$ & 3.14 & 0.66 & $\mathbf{1 . 8 0}$ & 4.7 \\
$\geq 80$ & 1.12 & 0.49 & $\mathbf{0 . 7 6}$ & 2.3 \\
\hline Overall & $\mathbf{5 2 . 3 7}$ & $\mathbf{1 0 . 9 5}$ & $\mathbf{3 1 . 6 0}$ & $\mathbf{4 . 8}$ \\
\hline
\end{tabular}

Source: Elaborated by the authors.

Figure 1 presents data regarding the Disability-Adjusted Life Years (DALY) by age group and sex. The total value of DALY was 32.05, similar to what we observed in Years Lived with Disability (YLD) due alcohol. Additionally YLD accounted for the large majority (98.6\%) of the DALY attributable to alcohol consumption in Brazil. This means that most costs were due to disability and not mortality. As seen in Figure 1, the burden starts in the 20 years age group, firstly in men, then in women. This loss peaks in the 44 age group with 158.10. Afterwards, there is a gradual decrease, with a similar pattern of the results in the first age groups.

Figure 1: DALY due alcohol consumption by sex and age

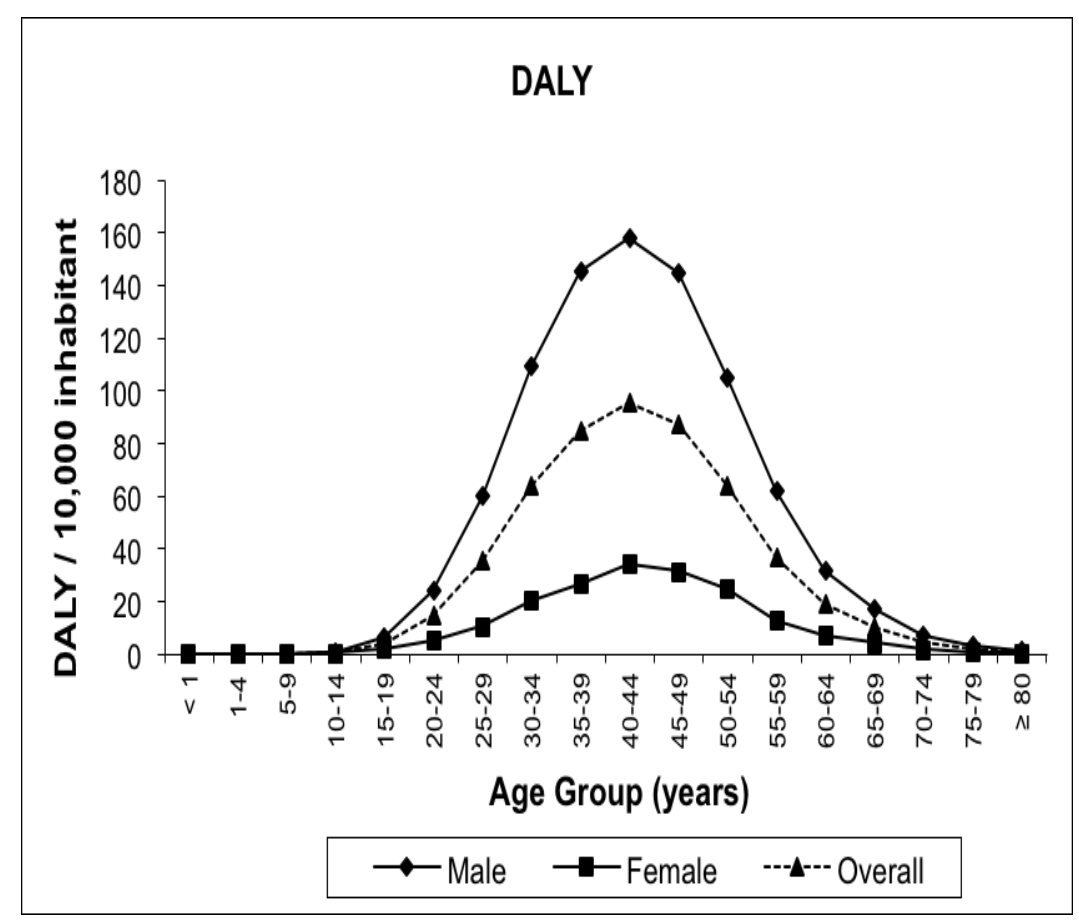

Source: Elaborated by the authors. 
Although alcohol use disorders (AUDs) do not rank high as cause of death globally. It has been ranked as the fourth-most disabling disease category in developing countries and third in developed countries (ORGANIZATION, 2008). In our study we found similar results, since the years lived with disability was significantly higher than the years of life lost due to alcohol consumption.

The discrepancy among sex was significant. Usually, men consume more quantity and often alcohol, and consequently present more alcohol related-problem (WILLNER, 2002). In this sense, our finding are similar with others studies (ZARIDZE et al., 2014 e CONNOR et al., 2005). Additionally, even if men have a shorter life expectancy in comparison with women, they presented a larger value of YLL. That is because the number of deaths related with alcohol among men was larger than among women.

The highest DALY values were found in the age group 40-44 years, starting to increase at the 20-24 years age group. These numbers were highest among the most productive age group of the population, which suggests that alcohol generates an impact in capital accumulation, as deaths and incapacity decreases wealth in society (HOFFMANN; MENDONÇA, 2003). The social burden and cost due to alcohol in Brazil has been national and international recognized and attributed to the lack of effective alcohol policies (REICHENHEIM et al., 2011; ANDERSON; CHISHOLM; FUHR, 2009 e BABOR; CAETANO, 2005).

In our results the YLD values contribute greatly to increase the DALY, as alcohol abuse has low lethality, and therefore it causes years lived with incapacity. Other chronic conditions (e.g. diabetes) follow the same tendency (LOPEZ, 2006). Even if YLD largely contributes to the DALY values, both YLD and YLL synthesize the magnitude of alcohol dependence and related harms on society and costs on the Brazilian health system.

The main limitation of this work was excluding other direct consequences caused by alcohol abuse, such as liver alcoholic disease, alcoholic cardiomyopathy and other. Furthermore, we used DATASUS as our source, we must consider that the number of cases might have been underestimated or registered with another code, which might have minimized our results. However, even if this study faced these limitations, the exploratory character of the research allowed us to explicit throughout DALY an estimate burden attributable to alcohol use. Hence, the innovative character of our proposal sheds new light on the debate. We believe that our study will be the key to monitor the burden caused by alcohol consumption in Brazil, so further investigation using DALY will allow characterizing the consequences of alcohol use over society.

\section{CONCLUSION}

The results of this study contribute for the understanding of alcohol related harms in Brazil. The impact of mortality and disability (DALY) due to alcohol use is superior in men when compared with women. They will make possible the execution of serial analysis in order to trace in a systematic matter the evolution of the pattern of alcohol abuse and its harms. This can consequently, support the formulation of prevention and education public policies so that the financial resources directed towards health are applied based on scientific evidence. Finally our results enable to question and to refine existing actions, seeking the search for better strategies that promote more responsible alcohol use and decrease individual and social harms. 


\section{REFERENCES}

ANDERSON, P; CHISHOLM, D; FUHR, D. C. Effectiveness and cost-effectiveness of policies and programmes to reduce the harm caused by alcohol. The Lancet, v. 373, n. 9682, p. 2234-2246, 2009

BABOR, T.F.; CAETANO, R. Evidence-based alcohol policy in the Americas: strengths, weaknesses, and future challenges. Rev Panam Salud Pública, vol.18, n.4, p.327-337, 2005.

CAMPOS, M. R., et al. Morbidity and mortality associated with injuries: results of the Global Burden of Disease study in Brazil, 2008. Cadernos de Saúde Pública, v. 31, n. 1, p. 121-136, 2015.

CEBRID. II Levantamento Domiciliar sobre o Uso de Drogas Psicotrópicas no Brasil - 2005. Brasília: Secretaria Nacional Antidrogas, 2005.

CONNOR, J.et al

. The burden of death, disease, and disability due to alcohol in New Zealand. $\mathbf{N} \mathbf{Z}$ Med J., vol.118, n.1213, 2005.

DOLL, L; BINDER, S. Injury Prevention Research at the Centers for Disease Control and Prevention. Am J Public Health, vol. 94, n.4, p.522-524, 2004.

GADELHA, A.M.J.; SCHRAMM, J.M.A.; OLIVEIRA, A.F.; et al. Relatório Final do Projeto Estimativa da Carga de Doença do Brasil - 1998. Escola Nacional de Saúde Pública/Fiocruz. Rio de Janeiro, 2002.

GALLASSI, A.D.; ELIAS, P.E.M.; ANDRADE, A.G. Caracterização do gasto SUS com internações de dependentes de substâncias psicoativas no período de 2000 a 2002 no município de Campinas - SP. Rev. psiquiatr. clín, vol.35, suppl.1, p. 2-7, 2008.

HOFFMANN, M.B.P.; MENDONÇA, S.E.A. O mercado de trabalho na região metropolitana de São Paulo. Estud Av., vol.17, n.47, p.21-42, 2003.

LARANJEIRA et al. Levantamento Nacional de Álcool e Drogas < INPAD > [Internet]. [cited 2013 Apr 12]. Available from: http://inpad.org.br/lenad/alcool/

LIM, S.S; VOS, T. et al. A comparative risk assessment of burden of disease and injury attributable to 67 risk factors and risk factor clusters in 21 regions, 1990-2010: a systematic analysis for the Global Burden of Disease Study 2010. The Lancet, vol.380, n.9859, p.2224-2260, 2012.

MINISTÉRIO DA SAÚDE B. Sistema de Informações Hospitalares (SIH) e Ambulatoriais [Internet]. 2009 [cited 2009 Jan 29]. Available from: http://portal.saude.gov.br

MURRAY, C.J. Quantifying the burden of disease: the technical basis for disability-adjusted life years. Bull World Health Organ, vol.72, n.3, p.429-445, 1994.

MURRAY, C.J.; LOPEZ, A.D. Global mortality, disability, and the contribution of risk factors: Global Burden of Disease Study. The Lancet, vol. 349, n.9063, p. 1436-1442, 1997.

NEDEL, F.B.; ROCHA, M.; PEREIRA, J. Years of life lost by mortality: a component of the burden of disease. Rev Saúde Pública, vol.33, n.5, p.461-469, 1999.

ORGANIZATION, W.H. The global burden of disease: 2004 update. World Health Organization, 156 p, 2008

REICHENHEIM, M.E.et al. Violence and injuries in Brazil: the effect, progress made, and challenges ahead. The Lancet, vol.377, n.9781, p.1962-1975, 2011. 
REHM, J.; MONTEIRO, M. Alcohol consumption and burden of disease in the Americas: implications for alcohol policy. Revista Panamericana de Salud Publica, v. 18, n. 4-5, p. 241-248, 2005.

SCHMIDT, M.I. et al. Chronic non-communicable diseases in Brazil: burden and current challenges. The Lancet, vol.377, n.9781, p.1949-1961, 2011.

WHITEFORD, Harvey A. et al. The global burden of mental, neurological and substance use disorders: an analysis from the global burden of disease study 2010. PlosOne, v. 10, n. 2, p. e0116820, 2015.

WILLNER, S. The Impact of Alcohol Consumption on Excess Male Mortality in Nineteenth- and Early Twentieth-Century Sweden. Hygiea Int, p.45-70, 2002.

ZARIDZE, D.et al. Alcohol and mortality in Russia: prospective observational study of 151000 adults. The Lancet, vol.383, n.9927, p.1465-1473, 2014. 
